\title{
The Meaning of Family in Fighting the Pathological Habit of Smoking Electronic Cigarettes
}

\begin{abstract}
Among the important pathological phenomena for our contemporary social life, among others, workaholism, internetoholism, addiction to mobile phones as well as drug addiction are listed. Smoking electronic cigarettes should also be regarded as an element of the phenomena exhibiting signs of addiction. Currently there are no formal restrictions that would not allow their use in public places. Their smoking is therefore dependent on the education and personal culture. Research conducted by the author of this paper confirms that the most important transmitter of culture is still the immediate family. In families then one should seek an ally in education to ensure that electronic cigarettes should not be smoked in public areas. The conclusion is therefore that education regarding treatment of electronic cigarettes as something bad and inappropriate should also cover the parents.
\end{abstract}

Key words: pathology, electronic cigarettes, family.

The description of the condition of modern society and possibilities of how to deal constantly emerging new problems depends on many factors. The most important ones include the economic model advocated by the evaluating person, their political beliefs and worldview. Let us say, for example, that the relaxation of the law with regard to euthanasia or the possibility of same-sex marriages will be considered by some as a benefit, and by others to be a major factor supporting the demoralization of society. For those who insist on the responsibility of an individual for taken actions, a law legalizing prostitution will be a challenge to greater personal responsibility. Supporters of the argument that the law also plays an important educational role will see it as an effective ally in the fight against 
deviations of our social life. The liberalization of the law in these areas will be seen as a harmful phenomenon expanding the areas of social pathologies. The above-mentioned deviations, given on exemplary basis - divorces, prostitution, euthanasia support - regardless of one's worldview are commonly classified as pathological phenomena. Taking our daily lives into consideration, we must admit that there still appear new pathological phenomena that affect the condition of populations. We include there, without argument, pedophilia, terrorism, workaholism, internetoholism and even phonoholism. Let us note that the issue of social pathologies is extremely popular with journalists who do not hesitate to put forward sharpen and superficial judgments. The author of this work would like to ask, from a deeper perspective, whether the new phenomena exhibiting pathological features include the habit of smoking electronic cigarettes. In the response to the above question there is a question to what extent and why the family should play a leading role in overcoming this addiction. First, however, the very concept of pathology will be explained and an attempt to classify it will be made. The article will be summed up with author's conclusions.

\section{The concept of social pathology}

Any dictionary or encyclopedia will say that the pathology belongs to the field of medical sciences dealing with the study of the formation processes of diseases, seeking their causes and consequences and their impact on the structure and further functioning of the body. This is quite understandable since the term "pathology" comes from the Greek words "páthos" and "logos". The first of the Greek words means experience, feeling, passion but also suffering. The second, in turn, "logos" is depicted in the Polish language with the word "science". Because it always related with disease-creating changes and deviations from the norm and therefore the term "pathology" is also used to describe social phenomena and changes. It should be noted that the term is used in the literature describing anti-social phenomena quite reluctantly. In the literature mentioning specific phenomena going beyond commonly accepted attitudes, terms such as addictions, deviations, anomalies and acts disintegrating the society are also used. Among other terms being used the following are also given "problematic behaviors", "high-risk" or "destructive behavior".

With the above observations in mind, we can broadly say that the pathology in the social sciences is all phenomena and behaviors that threaten the social order. In other words, they have destructive effects on the functioning of the body which is in this case is the society. Elżbieta Michałowska from the University of Lodz [2010, p. 68] writes that the phenomenon has clearly a negative connotation. It covers all phenomena which are clearly undesirable in the society. The author emphasizes that pathological attitudes deviate from the norm accepted in the 
society. Such definition, however, although quite commonly accepted [Budzeń 2014, p. 28], raises some difficulties. It is not yet easy to determine what is the social norm and what is not. The situation becomes even more serious when we consider the fact that we live in the time of universal globalization and migration of populations. An important element in this context, which is the percentage of the population recognizing a given phenomenon as pathological or expressing an opposite opinion, may therefore fairly quickly change.

When determining the social pathologies an important role is also played by the media. Widespread campaign to legalize civil unions leads to the belief that we are not dealing in this case with a deviation from the social norm. Twenty years ago such a judgment was radically different. The same is true for prostitution. Its legalization would probably change the common, negative evaluation of this phenomenon by a large part of the population as legalization of prostitution would bring social and economic advantages.

Social pathology can be understood in two ways. Referring to medicine, it can be said in general terms that it is a science dealing with the formation, causes and consequences of social behavior deviating from the widely understood environmental standard. Secondly, it is also a phenomenon that differs from commonly accepted attitudes. In the popular "Dictionary of sociological terms" developed by Małgorzata Pacholski and Andrzej Słaboń [2010, p. 150], social pathologies include "alcoholism, drug addiction, suicides, sexual deviations and sexual crime, prostitution, social maladjustment of children, minors and adolescents, murders and other crimes against life, economic crime, divorces". The above list was supplemented with unemployment, homelessness and domestic violence. One of the characteristics of modern times are phenomena that are destructive to the family. In addition to such well-known ones as drug addiction, addiction to medication, alcoholism, incest and infanticide one could add workaholism, infoholism, consumerism and children trafficking [Jędrzejko, Walancik, Janusz 2013, p. 38]. I believe that these examples of social pathologies allow a better understanding of the scope and concept of the very phenomenon.

These lists allow us to draw one simple conclusion. When discussing pathological phenomena it is sometimes difficult to talk about their uniqueness. In every period of our history we had to deal with suicide, prostitution, sexual deviations. Naturally, in our social context we should be talking about a certain intensification of these phenomena. Along with the ongoing industrialization and technological development we can indicate some new phenomena which have not been considered pathological before. We can include there mentioned above unemployment, but also environmental degradation, addiction to computers or the Internet. Let us also add phonoholism here. Pavel Mühlpachr [2004, pp. 8188 ] included gambling addiction to pathological phenomena as well. His research 
concerns the Czech Republic. We can say, however, that his observations are of general nature. Among the groups at risk of addiction to gaming machines Mühlpachr listed males, children and youth, professional players as well as the unemployed. Out of particular professions the author pointed out waiters and staff of gaming arcades.

Phenomena mentioned in this article are of universal character. Pathology specialists increasingly prefer to talk about deviations from the norm in the local perspective. In fact, certain pathologies disappear in one environment and intensify in another one; in one society they are perceived as negative ones less, and in a different society not so much.

The assessment whether the events are treated as pathological depends on many factors. The most important of them are demography, health, economic standing and cultural conditions of a society. In some environments smoking drugs has always been a good and acceptable cultural expression, in others it was considered a deviation. Other circumstances determining the pathologies include the degree of transformation, development of society and democratization of life, and even the educational system and its effectiveness. In evaluating the pathological phenomena one must also take into account certain subjective factors. In one group some attitudes will be considered destructive, and in a different one they will inspire emotions and admiration. Still there will be others who will consider them as neutral and will treat them as normal in their daily routines.

With a view of occurring changes and emergence of new deviations in mind, the author of this work asked a hundred students which pathologies they consider to be the most serious. The list included workaholism, drug addiction, internetoholism, phonoholism and smoking e-cigarettes. The question posed was also whether students consider the use of electronic cigarettes as a social pathology. We consider the results as a summary of the text so far. Specifically, 55 people recognized that the most serious pathology that affects the society is drug addiction. Phonoholism was indicated by 17 respondents, 16 mentioned internetoholism in the first place and 10 - workaholism. Only two respondents indicated the use of electronic cigarettes as a social pathology. Let us also note that smoking e-cigarettes usually mentioned on the fifth and sixth place. It is also worth noting that 12 respondents did not mention electronic cigarettes at all.

\section{The issue of electronic cigarettes and the educational role of the family}

Specialists dealing with social deviations pay attention to the fact that the pathologies most often intertwine and condition each other. Depending on the period, some have more destructive effect on the society, while others appear to be more soft. At the end of the previous section modern phenomena with pathological signs such as workaholism, drug addiction, phonoholism and 
internetoholism were listed. Let us recall that only two people indicated the use of electronic cigarettes and twelve did not reckon them as a social deviance at all. Further research was necessary. Indeed, respondents felt that the phenomenon of e-cigarette smoking raises some concerns. The author of this work asked the participants of the survey whether and in what areas they would prohibit the use of electronic cigarettes. The proposed list included this time: school, university, library, public transportation, restaurant, place of work, theater, cinema, museum and hospital. It should be emphasized that all respondents considered that there are places where the use of electronic cigarettes should be prohibited. Only two people did not provide any answer. Most respondents, as many as 42 , indicated hospital, 25 mentioned school in the first place, 8 - public transport, 7 gave theater as their answer. Among the places smoking e-cigarettes should be banned were also a restaurant -5 respondents, library -4 , place of work -3 , museum -2 . University and cinema were indicated by one person.

The belief that the use of electronic cigarettes is not something ordinary is strengthened by one observation. We must note at this point that smoking electronic cigarettes in Poland is not formally prohibited. A new law concerning the protection of health against the consequences of the use of tobacco and tobacco products, limiting the places where it is not allowed to smoke cigarettes, was passed on 8 April 2010. This law says that smoking is forbidden in health care facilities and other public buildings where health care is provided. This ban also includes organizational units of the educational and social care system as well as universities, cultural facilities and public leisure centers. Lawmakers have not forgotten about catering and entertainment premises, means of public transport, service centers for travelers, public transport stops, sports facilities, children's playgrounds as well as other areas available for public use. The legislature has allowed local authorities to name other places where smoking is banned.

In one of the few works devoted to smoking e-cigarettes where the phenomenon is included as a social pathology, Stanisław Kozak [2014, pp. 73-74] notes that e-cigarettes are not formally listed as tobacco products. The above-mentioned Act does not apply therefore to e-smokers. The author also claims that the ban on the use of electronic cigarettes is contrary to the Polish Constitution. According to our fifth article of the Basic Law, a prohibition constitutes a lack of respect for the freedom of the citizen. It is one of the main reasons why people using electronic cigarettes can be met almost everywhere. They can be encountered on the buses, in the cars, at public transport stops. These are all places that are not available to ordinary cigarette smokers. But we do not find them in hospital, schools and libraries. I asked several library staff and they said they did not allow e-smoking. They know, however, that there is no formal prohibition in this regard. I must confess that I was made to write this article by one of the students who started smoking e-cigarette during my lecture. I did not give her the permission to do so. 


\section{2}

There are a few observations worth pointing out as regarding e-cigarettes. Their very name can be understood as an ecological product, meeting environmental standards. Popular referring to the fact that the products are ecological has become so common that we probably got used to this simple advertising trick and do not take it seriously now. Electronic cigarettes contain nicotine, however. Like many other electronic devices they are reusable. Due to the ban on traditional smoking in many public places, they are popular among heavy tobacco smokers. Inhalation allows the adoption of purified nicotine and is less harmful to health [Co to jest e-papieros?]. In the context of smoking substances which contain nicotine, there is an important question of the amount of carcinogenic elements, i.e. harmful chemicals, in the electronic cigarette. According to previous studies, such cigarettes are free of carcinogenic tar substances or they are present in trace amounts. The smoke exhaled by smokers is also harmless to the public. Furthermore, e-cigarettes do not affect the change in blood pressure and pulse. This does not mean that in case of e-smoking there is no risk of cancer or diseases of the respiratory system. It is, however, much smaller than in the case of traditional cigarette smoking. For the time being, we need to admit that we do not yet have accurate results of research on the subject [Dyjecińska 2015, p. 2].

Let us try to analyze existing research conducted by the author of this paper. Survey participants indicated that electronic cigarettes are not considered to be one of the most important social pathologies. They pointed out, however, that they would limit the places where e-smoking should be banned. The author posed one more question to the same group of respondents: who had the most important influence on their upbringing and culture? For there is one basic reason to put such a question. Since, as yet, it is not possible to prohibit e-smoking, one would want to know where to look for allies in limiting the places available for heavy "smokers". Smoking or not using electronic cigarettes should be regarded from the perspective of one's education and personal culture. In addition, supporting one's case with legal prohibitions, although in this case could be effective, it does not always mean that one has to refer to legal means. Returning to the survey let us say that this time the list of possible answers included: the immediate family, school, television, radio and the Internet. The results were not surprising. 69 respondents indicated that the immediate family has the biggest impact on their education and manners, 12 mentioned the school, 10 - the Internet, and 9 television.

These studies show clearly and confirm scientific analyses that our immediate family has the greatest impact on the transmission of culture. It is the smallest unit of the society that most effectively carries out important social functions, which are necessary for the existence of society. One of the main functions include of the family is its socializing role. Kazimierz Pierzchała writes [2009, p. 73] that 
this role means "the introduction of family members in the life of the society and provides them with cultural values". It is extremely important in this context is that in families today that tolerance for different views of children and treating them as partners is increasing. Furthermore, the family is not treated as a formal institution but it is rather seen as an intimate community. Its members can freely express their controversial opinions, unpopular statements and philosophical beliefs. This allows families to open up to new phenomena such as, beyond any doubt, the use of electronic cigarettes. Pierzchała also underlines that in many cases the family "produces moral control in a child over their own behavior, shaping beliefs and thus makes an individual a member of a particular society as well as consumer and producer of its culture".

\section{Closing remarks}

In many publications it is noted that, depending on how strong the family is, the society will be able to resist social pathologies [Będkowska-Korpała 2009]. Elżbieta Michałowska [2001, p. 61] further notes that sources of many pathologies should be sought in dysfunctional families. She reminds that the family home is now the site of numerous tensions and stress. Parents demonstrate also a unique lack of time for their children. Simultaneously, as the author stresses, the most important feelings and beliefs are rooted in the relationship between parents and children. It is there where we should look for the source of moral and emotional order which, as Michałowska writes, is "the code for the whole life". Let us share then one more observation. We have no doubt that we need to make every effort to ensure that parents believe that the use of electronic cigarettes is harmful and should be regarded in the perspective of social pathologies having as yet unpredictable consequences for our future.

\section{Bibliography}

Będkowska-Korpała B. (2009), Uzależnienia w praktyce klinicznej. Zagadnienia diagnostyczne, PARPAMEDIA, Warszawa.

Budzeń H. (2014), Zjawiska patologiczne wysteppijace w rodzinach i ich wptyw na wychowanie džeci i młodzie ży [w:] M. Jędrzejko, E. Gładysz (red. nauk.), Patologie spoteczne. Przestepcrość, niedostosowanie spoteczne, A kademia Humanistyczno-Ekonomiczna w Lodzi.

Co to jest e-papieros?, http://www.e-papieros.edu.pl/co_to_jest_e-papieros.html, access 9 March 2015.

Dyjecińska J., E-papieros: škodliwy czy nie?, http://www.poradnikzdrowie.pl/psychologia/ nalogi/e-papieros-szkodliwy-czy-nie_42302.html, access: 9 March 2015.

Jędrzejko M., Walancik M., Janusz M. (2013), Patologie - uzależnienia: zjawisko i jego implikacje, ASPRA, Warszawa.

Kozak St. (2014), Patologia cyfrowego dziecinstwa i mtodości. Przyczyny, skutki, zapobieganie w rodzinach i w szkołach, Difin, Warszawa. 


\section{Grzegorz Ignatowski}

Michałowska E. (2010), Mięzy rygoryzmem a tolerancja. Młodzi wobec zjawisk patologii społecznej, Wydawnictwo Uniwersytetu Lódzkiego.

Michałowska E. (2004), Wptyw środowiska sækolnego na percepcje $i$ ocene zjawisk patologii spotecznej przez. mtodzież, „Przegląd Socjologiczny”, 2001, no.1, pp. 59-72.

Mühlpachr P. (2004), Uzależnienie od automatów do gier [in:] M. Prokosz (ed.), Dewiacyjne aspekty współczesnego świata. Przejawy, zapobieganie, terapia, Wydawnictwo Adam Marszałek, Toruń.

Pacholski M., Słaboń A. (2010), Stownike pojéć socjologicznych, Wydawnictwo Uniwersytetu Ekonomicznego w Krakowie.

Pierzchała K. (2009), Rodzina - jej definicja i funkcje [in:] K. Pierzchała, Cz. Cekierka (ed.), Człowiek a patologie społeczne, Wydawnictwo Adam Marszałek, Toruń.

Ustawa z dnia 8 kwietnia 2010 r. o zmianie ustawy o ochronie zdrowia przed następstwami używania tytoniu i wyrobów tytoniowych oraz ustawy o Państwowej Inspekcji Sanitarnej, http://isap.sejm.gov.pl/DetailsServlet?id=WDU20100810529, access: 9 March 2015. 